\title{
Adding Zero-Valent Iron to Enhance Electricity Generation during MFC Start-Up
}

\author{
Chao Li ${ }^{1,2}$, Kang Zhou ${ }^{1,2}$, Hanyue He ${ }^{3}$, Jiashun Cao ${ }^{1,2, *}$ and Shihua Zhou ${ }^{4}$ \\ 1 Key Laboratory of Integrated Regulation and Resource Development on Shallow Lakes, \\ Ministry of Education, Hohai University, Nanjing 210098, China; lichao_hhu@hhu.edu.cn (C.L.); \\ zk2416962322@163.com (K.Z.) \\ 2 College of Environment, Hohai University, Nanjing 210098, China \\ 3 Jiangsu Yuzhi River Basin Management Technology Research Institute, Nanjing 210000, China; \\ hehanyue19940504@163.com \\ 4 Third Design and Research Institute, Shanghai Municipal Engineering Design and Research General \\ Institute, Shanghai 200092, China; zhoushihua@smedi.com \\ * Correspondence: lichao0609@163.com; Tel.: +86-158-5051-5154
}

Received: 13 December 2019; Accepted: 22 January 2020; Published: 28 January 2020

\begin{abstract}
The low power generation efficiency of microbial fuel cells (MFCs) is always a barrier to further development. An attempt to enhance the start-up and electricity generation of MFCs was investigated by adding different doses of zero-valent iron into anaerobic anode chambers in this study. The results showed that the voltage $(289.6 \mathrm{mV})$ of A2 with $0.5 \mathrm{~g}$ of zero-valent iron added was higher than the reference reactor $(197.1 \mathrm{mV})$ without dosing zero-valent iron (A4). The maximum power density of $27.3 \mathrm{~mW} / \mathrm{m}^{2}$ was obtained in A2. CV analysis demonstrated that A2 possessed a higher oxidation-reduction potential, hence showing a stronger oxidizing property. Meanwhile, electrochemical impedance analysis (EIS) also manifested that values of RCT of carbon felts with zero-valent iron supplemented $(0.01-0.03 \Omega$ ) were generally lower. What is more, SEM images further proved and illustrated that $\mathrm{A} 2$ had compact and dense meshes with a hierarchical structure rather than a relatively looser biofilm in the other reactors. High-throughput sequencing analysis also indicated that zero-valent iron increased the abundance of some functional microbial communities, such as Acinetobacter, Ignavibacteriales, Shewanella, etc.
\end{abstract}

Keywords: microbial fuel cells (MFCs); electricity generation; zero-valent iron; oxidation-reduction potential; microbial communities

\section{Introduction}

Energy crisis and environmental contamination have been pushing researchers to search for new kinds of sustainable, renewable, and clean energy [1]. Microbial fuel cells (MFCs) are a green bioenergy technology, which are considered as a newly bioelectrochemical device that can convert available organic matters into electricity by exoelectrogenic bacteria attached on the anode [2,3]. Therefore, MFCs offer a new opportunity for simultaneous wastewater treatment and electricity generation [4]. At present, many efforts have been made to improve the performance of MFCs [5-7] and many works have focused on the microbial community composition of the anode biofilm [8]. However, little attention has been devoted to the effect of metal elements on the biofilm during start-up in MFCs.

In recent years, many metals and their oxides were used to modify the cathode or anode of MFCs in an attempt to improve the ability to transfer electrons in reactors. In MFCs, the pass-way of the anode's extracellular electrons transfer can be divided into direct electron transfer and indirect electron transfer [9-11]. The former is transferred by the microbial extracellular cytochrome or "nanowires" 
while a soluble redox mediator is needed in the latter. Furthermore, transfer mediators can be added exogenously or endogenously [12,13], and microbes use their own redox secretion or extraneous substances to facilitate electron transfer extracellularly, and then to the electrode surface $[14,15]$. The addition of metal elements can not only improve electrical performance directly but also play an important role in the culture of exoelectrogenic bacteria.

Studies show that the electrical performance of MFCs depends largely on the number of exoelectrogenic bacteria enriched on the anaerobic biofilm, most of which belong to iron-reducing bacteria (IRB). Moreover, a further study found that adding Fe (III) oxide to MFCs could enrich exoelectrogenic bacteria and also enhance the electrical performance of reactors. For example, Zhang et al. [16] pointed out that the addition of $\mathrm{Fe}(\mathrm{OH})_{3}$ enhanced both anaerobic digestion and anodic oxidation, resulting in an effective mineralization of volatile fatty acids (VFAs), which was beneficial for improving anodic oxidation and enhancing microorganisms' growth. Also, Wu et al. [17] demonstrated that Fe (III) supplemented into MFCs resulted in increased electricity generation by Shewanella oneidensis MR-1.

Zero-valent iron, the most basic form of iron, has seldom been used directly in the research of MFCs and it is in a doped or oxidized state. However, zero-valent iron, ferrous, or ferric iron is inextricably linked by accepting and losing electrons in redox reactions. It was assumed that zero-valent iron was likely to enhance the conversion of propionate to acetate because it could serve as an electron donor in microbial metabolism [18] and promote the activities of key enzymes in the acetogenesis process [19,20]. Interestingly, it is generally believed that acetic acid [21] could act as an appropriate substrate for exoelectrogenic bacteria, thus the power generation of MFCs is greatly improved.

However, the mechanism of zero-valent iron obtained in MFCs during start-up has been rarely reported. To gain insight into understanding the effects of zero-valent iron on MFC, the electron transfer property, anode biofilm formation, and biological community were investigated and analyzed in MFCs with different amounts of zero-valent iron addition in this study.

\section{Materials and Methods}

\subsection{Experimental Device}

H-type MFC devices consisted of two-cylinder transparent polyacrylic plastic bottles $(18 \mathrm{~cm} \times$ $\Phi 12 \mathrm{~cm}$ ), separated by a proton exchange membrane (PEM) (Nafion 117, Dupond, Hayward, CA, USA), whose inner diameter was $2 \mathrm{~cm}$. Each chamber has a carbon felt electrode $(5 \mathrm{~cm} \times 6 \mathrm{~cm} \times 0.2$ $\mathrm{cm}$, US Morgan). The electrode space is $15 \mathrm{~cm}$ and connected with an external resistance of $1000 \Omega$ as shown in Figure 1. Before experiments, the MFC components were sterilized with an autoclave at 121 ${ }^{\circ} \mathrm{C} 15 \mathrm{~min}$. All MFCs were operated in a temperature-controlled room at $25^{\circ} \mathrm{C}$.

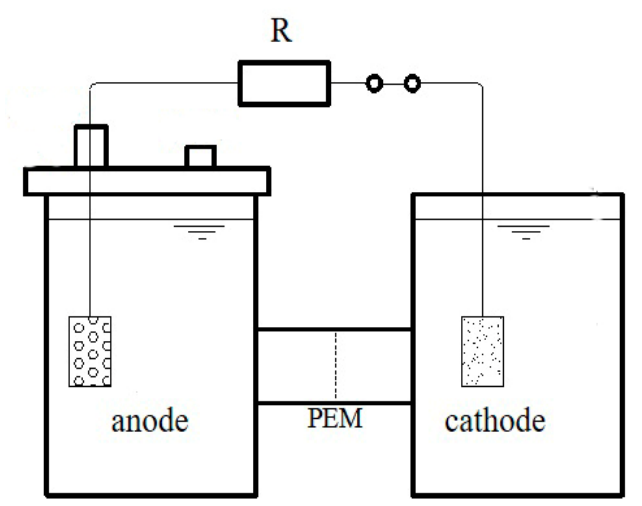

Figure 1. Schematic diagram of the MFC reactor used during the experiment. 


\subsection{Experimental Methods}

Experiments were conducted in batch mode with four parallel two-chamber MFCs containing four different concentrations of zero-valent iron: $0.1 \mathrm{~g}$ of zero-valent iron added (A1), $0.5 \mathrm{~g}$ of zero-valent iron added (A2), $1 \mathrm{~g}$ of zero-valent iron added (A3), and no zero-valent iron added (A4).

The two chambers, both filled with electrode medium ( $\mathrm{pH} 7.0)$, contained: $\left(\mathrm{NH}_{4}\right)_{2} \mathrm{SO}_{4}(0.56 \mathrm{~g} / \mathrm{L})$, $\mathrm{KCl}(0.13 \mathrm{~g} / \mathrm{L}), \mathrm{NaH}_{2} \mathrm{PO}_{4}(4.22 \mathrm{~g} / \mathrm{L}), \mathrm{Na}_{2} \mathrm{HPO}_{4}(2.75 \mathrm{~g} / \mathrm{L}), \mathrm{MgSO}_{4} \cdot 7 \mathrm{H}_{2} \mathrm{O}(0.2 \mathrm{~g} / \mathrm{L})$, and $1 \mathrm{~mL} / \mathrm{L}$ of trace elements solution, containing: $\mathrm{H}_{3} \mathrm{BO}_{3}(2 \mathrm{mg} / \mathrm{L}), \mathrm{FeCl}_{2} \cdot 4 \mathrm{H}_{2} \mathrm{O}(2 \mathrm{mg} / \mathrm{L})$, EDTA $(2 \mathrm{mg} / \mathrm{L}), \mathrm{ZnCl}_{2} \cdot 4 \mathrm{H}_{2} \mathrm{O}$ $(0.4 \mathrm{mg} / \mathrm{L}), \mathrm{MnCl}_{2} \cdot 4 \mathrm{H}_{2} \mathrm{O}(0.8 \mathrm{mg} / \mathrm{L}), \mathrm{CuCl}_{2} \cdot 2 \mathrm{H}_{2} \mathrm{O}(0.2 \mathrm{mg} / \mathrm{L}),(\mathrm{NH} 4)_{6} \mathrm{MO}_{7} \cdot 4 \mathrm{H}_{2} \mathrm{O}(1.1 \mathrm{mg} / \mathrm{L})$, and $\mathrm{NiCl}_{2} \cdot 6 \mathrm{H}_{2} \mathrm{O}(1 \mathrm{mg} / \mathrm{L})$. Sodium acetate was controlled at COD (Chemical Oxygen Demand) of $800 \mathrm{mg} / \mathrm{L}$ in the anodic solution.

The sludge was obtained from the sedimentation tank of a municipal sewage plant in Nanjing (China). After removing large debris, the volatile suspended sludge (VSS) was $4.4 \mathrm{~g} / \mathrm{L}$ and total suspended sludge (TSS) was $8.0 \mathrm{~g} / \mathrm{L}$.

The anaerobic digester sludge was inoculated in the anode compartment $(15 \%, v / v)$ as the biological catalyst, whereas the cathode compartment was continuously aerated with air.

\subsection{Electrochemical Analysis}

The voltage was measured by a voltmeter, and polarization curves for the MFCs were generated by changing the external resistance in the range 10-10,000 $\Omega$. Power density was calculated using the formula, $p=\mathrm{UI} / \mathrm{A}$, where $\mathrm{U}$ denotes the voltage between the anode and cathode, I denotes the current calculated from Ohm's law, and A denotes the area of the anode carbon felt.

Cyclic voltammetric characterization of the oxide electrode was performed in the potential range of -0.7 to $0.7 \mathrm{~V}$ with respect to the calomel electrode (NCE), and Pt wire was used as the counter electrode in the phosphate buffer. The impedance spectra of the anode film were recorded in the frequency range from $100 \mathrm{kHz}$ to $10 \mathrm{mHz}$ with the alternating current $(\mathrm{AC}$ ) amplitude of $10 \mathrm{mV}$, and the data collected were analyzed by using Zsimpwin software [22].

\subsection{Chemical Analysis}

TSS, VSS, and COD were conducted in accordance with Standard Methods for the Examination of Water and Wastewater [23]. The morphology of the four anodes was subjected to scanning electron microscopy (SEM) by cutting off $0.5 \mathrm{~cm} \times 0.5 \mathrm{~cm} \times 0.2 \mathrm{~cm}$ pieces.

\subsection{High-Throughput Sequencing (Miseq)}

High-throughput sequencing of the $16 \mathrm{~S}$ rRNA gene (Miseq, Illu-mina) was conducted for further analysis of the key four sludge samples. The sequencing and data analysis were performed by the Zhongyijinda Analytical \& Testing Co., Ltd (Jiangsu; China). The heatmaps and cluster analyses were obtained using the R programming language (R-3.1.0).

\section{Results and Discussion}

\subsection{Effect of Zero-Valent Iron on Voltage of MFCs during Start-Up}

The voltage output of four groups increased slowly at first and finally became stable in MFCs supplemented with different concentrations of zero-valent iron, as shown in Figure 2. The voltage of A2 was the highest, which could reach up to $289.6 \mathrm{mV}$, and the voltages of A1 and A3 had no big difference, with a maximum of 215.3 and $204.3 \mathrm{mV}$, respectively. Surprisingly, the voltage of A4 could only reach the peak of $197.1 \mathrm{mV}$. In addition, it can be found that $\mathrm{A} 2$ took $400 \mathrm{~h}$ to reach the voltage platform while A1 took $420 \mathrm{~h}$ and A3 and A4 still had a rising tendency after $500 \mathrm{~h}$, suggesting that the addition of zero-valent iron accelerated the start-up of the reactors. Zero-valent iron substantially 
affected the voltage production as well as the voltage platform during the start-up period of MFCs, and the highest voltage was observed with the appropriate concentration range.

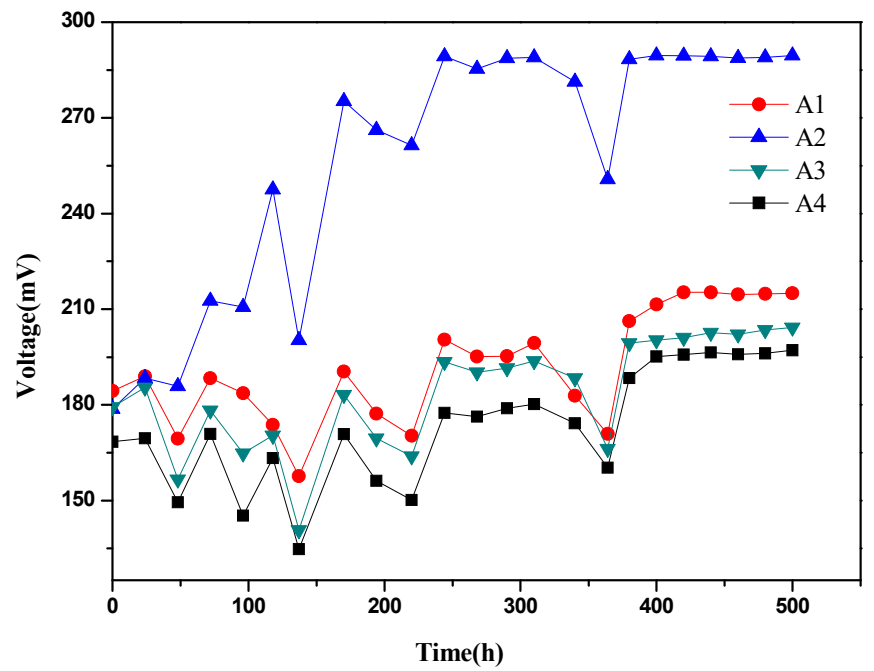

Figure 2. Cell voltage as a function of time with an external resistance of $1000 \Omega$ during start-up (A1: $0.1 \mathrm{~g}$ zero-valent iron; A2: $0.5 \mathrm{~g}$ zero-valent iron; A3: $1 \mathrm{~g}$ zero-valent iron; A4: no zero-valent iron).

\subsection{Effect of Zero-Valent Iron on Power Density of MFCs during Start-Up}

Figure 3 illustrates the power density of the MFC with a varying zero-valent iron concentration. MFCs supplemented with zero-valent iron during start-up showed higher power densities than that obtained in the control without zero-valent iron. The maximum power density of $27.3 \mathrm{~mW} / \mathrm{m}^{2}$ in the presence of $0.5 \mathrm{~g}$ of zero-valent iron was obtained, compared to $8.5 \mathrm{~mW} / \mathrm{m}^{2}$ without zero-valent iron. Meanwhile, A1 delivered a maximum power density of $20.8 \mathrm{~mW} / \mathrm{m}^{2}$ and A3 reached the peak of $10.0 \mathrm{~mW} / \mathrm{m}^{2}$. Furthermore, the power density was decreased when the zero-valent iron concentration further reached $1.0 \mathrm{~g}$. An increase in the power density occurred at first and then decreased as the current density increased because of the polarization of internal resistance. The results showed good consistency with the observed voltage, indicating that zero-valent iron could greatly enhance the power generation of MFCs at low concentrations; however, the reaction would be inhibited at higher concentrations. Jia et al. [24] also verified that the addition of ZVI to the digestion could retard excessive acidification by promoting butyric acid conversion and accumulating direct interspecies electron transfer simultaneously to enhance the biosensor's performance under a moderate amount of ZVI. The reason for this phenomenon could be explained as follows. On the one hand, $\mathrm{Fe}^{2+}\left(\mathrm{Fe}^{0}+2 \mathrm{H}^{+}\right.$ $=\mathrm{Fe}^{2+}+\mathrm{H}_{2}$ ) would be released when supplemented with a moderate dose, which changes the iron's strength inordinately and compresses the electric double layer of sludge effectively $[25,26]$. On the other hand, zero-valent iron would decrease reactors' ORP and reduce the accumulation of propionate, which facilitates the conversion of macromolecular acids to a smaller molecule [27]. 


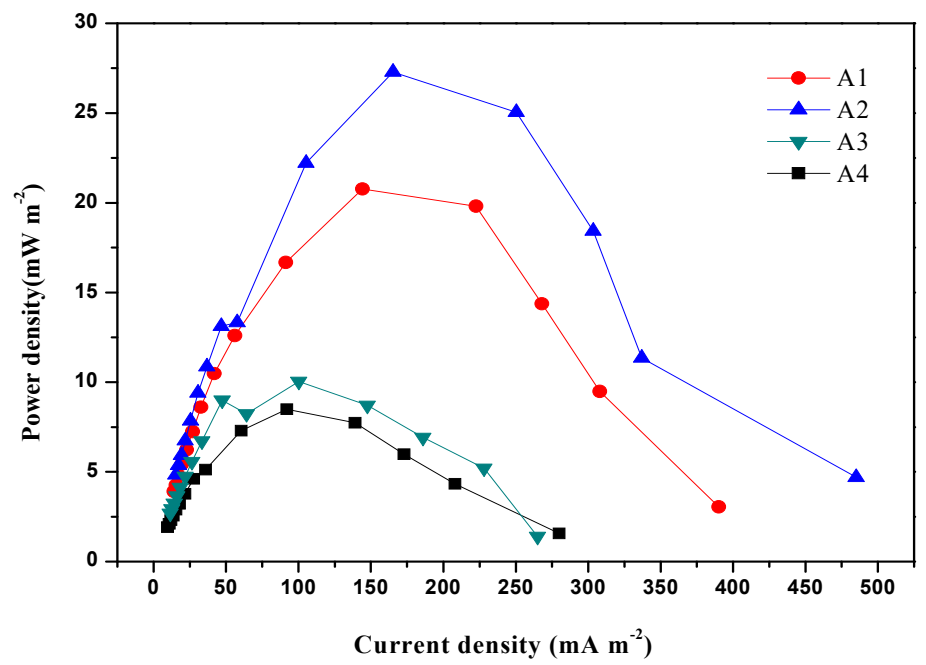

Figure 3. Power-density curves during start-up (A1: 0.1 g zero-valent iron; A2: 0.5 g zero-valent iron; A3: 1 g zero-valent iron; A4: no zero-valent iron).

\subsection{Electrochemical Activity of MFCs}

Cyclic voltammetry (CV) enables direct detection of redox signals, senses potential differences across the interface, and helps elucidate electrochemical reactions occurring at electrode surfaces [28], so CVs were tested during stable current generation to evaluate the importance of zero-valent iron on anodic electrochemical behavior. A single peak showing no retracing trend indicated this process was irreversible, as shown in Figure 4. The rate of ipa/ipc of these two peak currents was unequal to 1, which also confirmed this judgment. Furthermore, the gap of the peak potential between the anode and cathode was aggregated, illustrating that the irreversible degree became larger, namely, $\Delta \mathrm{Ep}>>$ $\mathrm{Upa}-\mathrm{Upc} \approx 0.056 / \mathrm{n}[29,30]$.

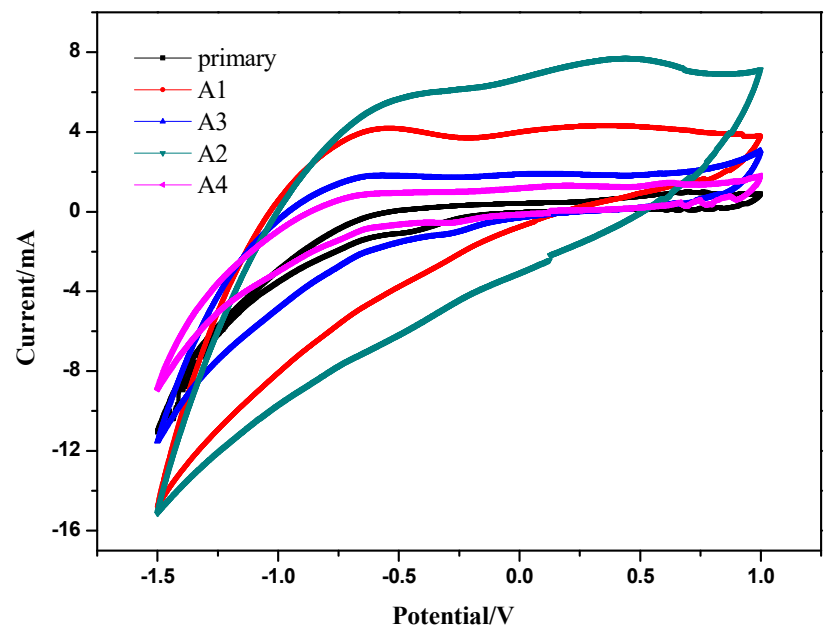

Figure 4. CV curves of anodic carbon felt of MFCs (A1: $0.1 \mathrm{~g}$ zero-valent iron; A2: $0.5 \mathrm{~g}$ zero-valent iron; A3: $1 \mathrm{~g}$ zero-valent iron; A4: no zero-valent iron).

No big difference in the irreversible degrees between each reactor supplemented with different doses of zero-valent iron was found, but there were still a couple of weakly defined redox peaks at -0.6 (A1) and $0.5 \mathrm{~V}(\mathrm{~A} 2)$, and the CVs of the zero-valent iron added exhibited a broader current range, suggesting zero-valent iron might produce redox mediators. As we all know, the redox potential can reflect the macroscopic oxidation-reduction property of substances in aqueous solution; the higher the oxidation-reduction potential, the stronger the oxidation ability. In Figure 4, the oxidation-reduction potential of A2 was higher than A1, showing that the oxidation ability of A2 was stronger and the 
solution was oxidizing. In addition, the areas of five closed redox curves varied dissimilarly, specifically A2 $>$ A1 $>$ A3 $>$ A4 $>$ primary carbon felt. It has been pointed out that the area of $\mathrm{CV}$ can reflect the amount of electricity exchanged between the oxidation and reduction reactions of an electro-active material, which can also demonstrate the polarization state of the internal electrode as well as the utilization of active substance [31,32]. So, it can be inferred that A2 has the most electro-active substances and its utilization rate of exoelectrogens was relatively higher.

Combined with the analysis above, A2, which had a suitable dose of zero-valent iron added, exhibited excellent electrochemical activity. The positive oxidation potential illustrated the reaction was more oxidizing and the metabolism of exoelectrogens on the surface of the electrode was more active. However, the oxidation peak of A3 was suppressed, because the addition of excessive zero valent iron inhibited the partial oxidation of anode microorganisms in the MFC, which probably weakened the redox reaction. Therefore, it was possible that the overall performance of MFCs could be improved by choosing an optimal concentration of zero-valent iron in the anode solution.

EIS (electrochemical impedance spectroscopy) was used to measure anode properties, such as the internal resistance and coating layers [33]. In MFCs, the performance of the anode is mainly affected by electrode reaction kinetics and mass diffusion. So, in order to figure out the effects of different doses of zero-valent iron on the internal transfer impedance and distribution of electro-active biofilm, the EIS of different electrodes was tested. As we all know, the charge between the surface of the electrode and contacted electrolyte solution was the opposite, forming an electric double layer capacitance. Meanwhile, electron transfer resistance also formed due to asynchronization of the electronic transfer, and differences between the electronic conductivity and solution ion conductivity when electrons were transferred on the interface of electrode/electrolyte. What is more, a diffusion layer trend is formed by solution ions under the effect of the voltage, and the electrolyte solution itself also has a certain impedance.

Nyquist plots are shown in Figure 5. It could be seen from the curves that all five carbon felts have the shape of a circular arc, representing resistance when electrons transfer inside it, and a straight line close to $45^{\circ}$. According to polarization theory, diffusion impedance exhibits a straight line at low frequency, suggesting that Warburg impedance, which is caused by the diffusion of oxygen in electrolyte solution outside the electrode, is formed and has the characteristic of semi-infinite diffusion. Th arc diameter is relatively larger in an open circuit because it is related to the exchange current density of the oxygen reduction reaction $[34,35]$.

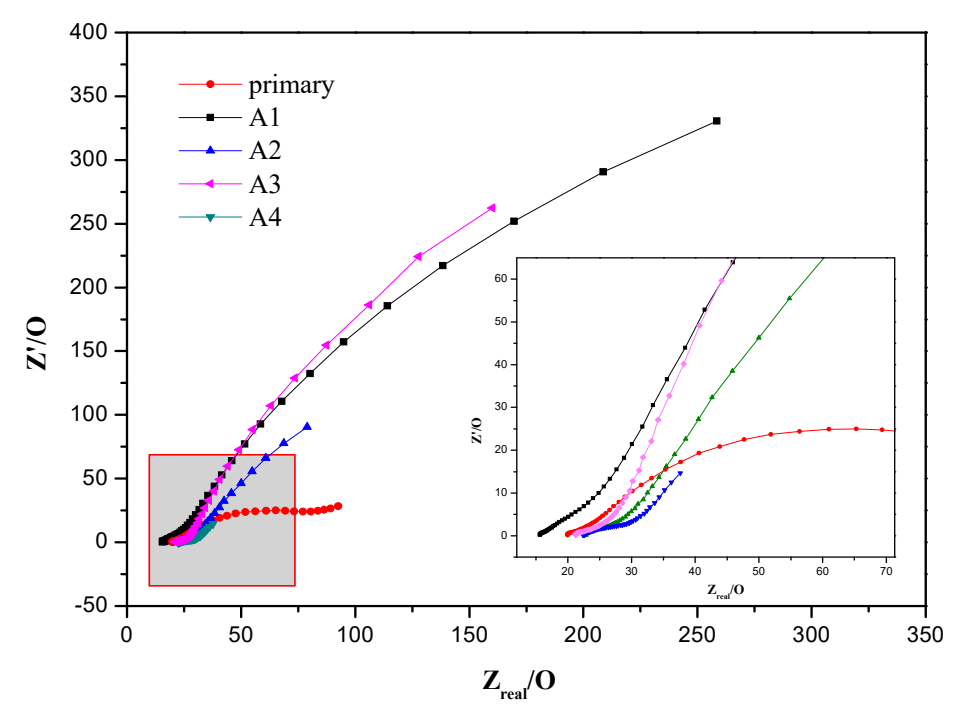

Figure 5. Impedance spectra (Nyquist) of anodic carbon felt of MFCs (A1: $0.1 \mathrm{~g}$ zero-valent iron; A2: $0.5 \mathrm{~g}$ zero-valent iron; A3: $1 \mathrm{~g}$ zero-valent iron; A4: no zero-valent iron). 
The experimental spectra were fit into an equivalent circuit according to Wagner to estimate the impedance data quantitatively using Zsimpwin software [22]. Values of the circuit elements are given in Table 1. Especially, the equivalent circuit included a charge transfer resistance $\left(R_{C T}\right)$, a constant phase element $(C$ in parallel, and a Warburg impedance $(\mathrm{W})$. The kinetics of the electrochemical reaction could be summarized from the faradic impedance, including the combination of $R_{C T}$ and $W$ [36].

Table 1. The Alpha diversity of the four activated sludge reactors.

\begin{tabular}{|c|c|c|c|c|}
\hline & $\mathbf{R}_{S} / \Omega$ & $\mathrm{R}_{\mathrm{CT}} / \Omega \times 10^{-3}$ & $\mathrm{C} / \mathrm{F} \times 10^{-3}$ & $W /\left(S \bullet s^{-0.5}\right) \times 10^{-3}$ \\
\hline A1 & 18.44 & 25.600 & 0.0290 & 1.53 \\
\hline $\mathrm{A} 2$ & 24.71 & 10.000 & 27.9 & 11.9 \\
\hline A3 & 22.76 & 32.470 & 2.26 & 0.330 \\
\hline A4 & 23.98 & 33,840 & 1.12 & 23.8 \\
\hline primary & 22.24 & 35,730 & 0.360 & 70.2 \\
\hline
\end{tabular}

In this electrochemical system, the arc appearing at high frequency represented $R_{S}$ (ohmic resistance) since the structure of the working electrode carbon felt was porous. The fitted data suggested that $R_{S}$ were close to each other [37,38], with an average value of $22.43 \pm 2.18 \Omega$ under different doses of zero-valent iron. This was because $R_{S}$ mainly depends on the configuration of the reactor while the catalytic effect is not significant. In addition, there were two other processes in the solution: Charge transfer and mass transfer. $\mathrm{R}_{\mathrm{CT}}$ (charge transfer internal resistance) is caused by the energy activation barrier, which needs to be overcome during an electro-chemical reaction, while mass transfer resistance indicates the effect of mass diffusion on the electrode and it can be defined as semi-infinite diffusion by the shape in the study.

$\mathrm{R}_{\mathrm{CT}}$ in Table 1 showed that the $\mathrm{R}_{\mathrm{CT}}$ of carbon felts with zero-valent iron supplemented were generally low while values with no zero-valent iron supplemented were sharply increased. After a period of domestication, a layer of biofilm attached, with zero-valent iron forming and then adsorbing on the electrode surface so that electrons produced by exoelectrogens could be transferred by this biofilm, thereby reducing $\mathrm{R}_{\mathrm{CT}}$. $\mathrm{R}_{\mathrm{CT}}$ in $\mathrm{A} 2$, which had $0.5 \mathrm{~g}$ of zero-valent iron added, had the lowest value $(0.01 \Omega)$ while A4 $(33.84 \Omega)$ with no zero-valent iron added had the highest (except primary carbon felt). Combined with SEM above, the biofilm of A2 was relatively enriched and electro-active microorganisms continuously adhered to the electrode, which hastened the electron transfer rate of carbon felts and reduced their resistance. Hence, it was possible to confirm that the high values of the voltage and power density precisely contributed to the low $\mathrm{R}_{\mathrm{CT}}$, which improved the electron transfer efficiency and enhanced the electrochemical performance. However, $\mathrm{W}$ (Warburg impedance) of A2 was relatively high because the biofilm enriched in A2 was mature, abundant, and thick. Correspondingly, there were less electro-active microorganisms in A4, so the resistance was higher during the mass transfer process and mass diffusion was more difficult, which caused the high value of $\mathrm{R}_{\mathrm{CT}}$. In addition, it was found that the second arc of primary carbon felt was biased and it was not a strictly semi-infinite diffusion, appearing as the shape of an arc because of the lack of biofilm enrichment and poor conductive properties.

\subsection{SEM Images of the Anode Surface of MFCs}

As a corollary, the high performance of electricity generation could contribute to the large number of enriched biofilms on the carbon felt surface. In light of this, SEM analysis was conducted to make morphological observations of carbon felts supplemented with different doses of zero-valent iron. SEM images (Figure 6) recorded at high magnification clearly showed compact and dense meshes with a hierarchical structure, which had $0.5 \mathrm{~g}$ of zero-valent iron added (A2). Meanwhile, the biofilm of A1 was relatively porous with a looser and irregular structure and A3 or A4 showed a very loose biofilm shape, exhibiting a smaller specific surface area with no lattice-like structure. Combined with the voltage and power density discussed above, it could be concluded that carbon felt enriched with 
more biofilms had a better electric performance. The reason could be illustrated as follows. The parts where enriched biofilms had more exoelectrogens and electrochemically active microbes, which were comprised mainly of cytochromes, served as electron conduits between intracellular catabolic reactions and extracellular conducive materials (e.g., electrodes) [39], and had unique extracellular electron transport pathways. As we all know, some electroactive microorganisms are recognized as dissimilatory iron-reducing bacteria, which can access iron as an electron acceptor to transfer electrons during the respiration process [40]. As a result, the addition of zero-valent iron to MFC reactors could culture and catalyze the production of iron-reducing bacteria.

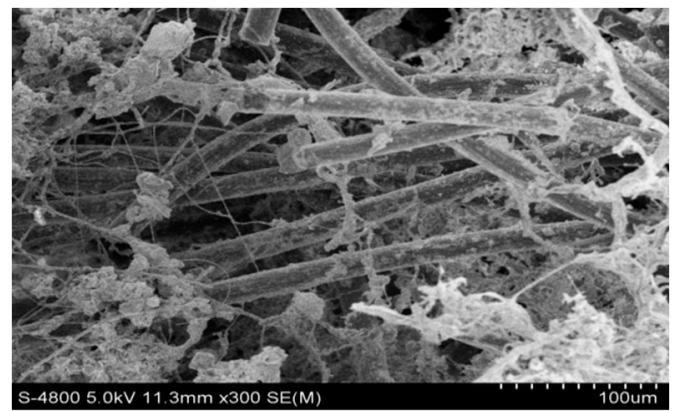

(a)

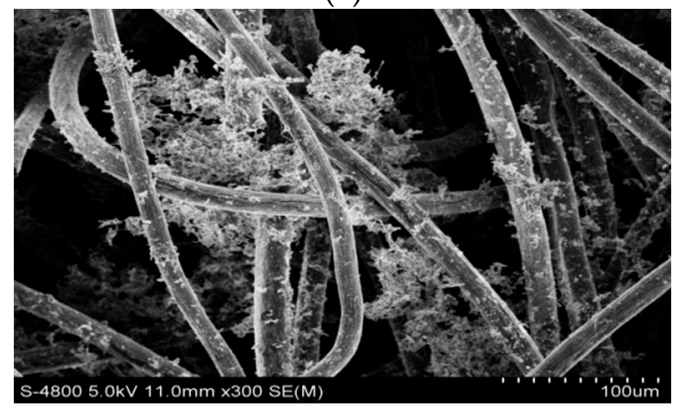

(c)

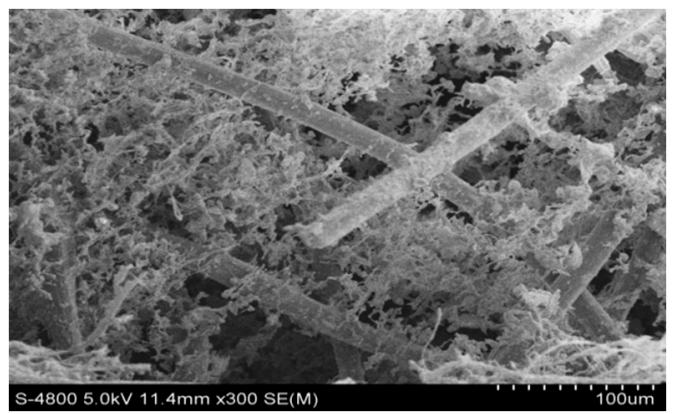

(b)

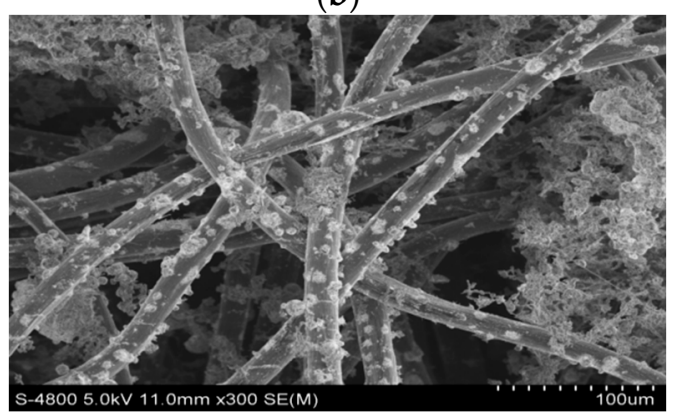

(d)

Figure 6. SEM images of the anode surface of three MFCs (a) A1; (b) A2; (c) A3 (d) A4.

Zero-valent iron in the A1 reactor was the least, and the growing environment provided for microorganisms was mild and suitable, causing the acclimation of exoelectrogens and an improvement of the power generation. When the concentration of zero-valent iron was continuously increased, i.e., in the A2 reactor, microorganisms seemed to adjust the changes, so on the one hand, the enzyme activity and biological reaction rate were further improved, and on the other hand, the presence of a little amount of oxygen in the anodic reactor would gradually oxidize zero-valent iron, forming iron oxides deposited on the surface of zero-valent iron to avoid direct contact between zero-valent iron and microorganisms, which reduced the inhibitory effects on the activity of the exoelectrogens. However, organic matter would be constantly consumed by microorganisms as the dose further increased, exposing more zero-valent iron and releasing excessive iron ions, which had a toxic effect on exoelectrogens and inhibited their activity, consequently showing a rapid reduction in voltage. This phenomenon is supported by Antwi et al. [41], who pointed out that the effect of the addition of $0,1,4$, 10 , and $20 \mathrm{~g} / \mathrm{L} \mathrm{ZVI}$ on the microbial community structure was different and the microbial community shift was most pronounced in assays with 10 and $20 \mathrm{~g} / \mathrm{L} \mathrm{ZVI}$.

\subsection{High-Throughput Sequencing and Microbial Community Analysis}

The DNA was extracted from biofilms sampled from all anodes. According to Table 2, A2 with $0.5 \mathrm{~g}$ of zero-valent iron added owned the highest biodiversity (Shannon index $=6.49$ ) while A4 with no zero-valent iron added owned the lowest biodiversity (Shannon index $=5.76$ ). So, it was indicated that supplementation of zero-valent iron could influence the distribution of the microbial community. 
Table 2. Analysis of diversities according to high-throughput sequencing.

\begin{tabular}{cccccc}
\hline & OTUs & Chao & Shannon & ACE & Simpson \\
\hline A1 & 3495 & $10,386.96$ & 6.104079 & $17,856.5333$ & 0.011626 \\
A2 & 4578 & $15,520.60$ & 6.492959 & $29,822.3437$ & 0.013034 \\
A3 & 3539 & $10,659.00$ & 5.786235 & $18,800.1165$ & 0.026910 \\
A4 & 2762 & 6914.500 & 5.765082 & $10,409.8210$ & 0.020122 \\
\hline
\end{tabular}

At the phylum level, bacterial species in the anode biofilm were dominated by Proteobacteria, Bacteroidetes, and Firmicutes, followed by Actinobacteria, Chloroflexi, Planctomycetes, Acidobacteria, and others. In the community, the Proteobacteria phylum was the most abundant in all samples and it was present at higher percentages in both A2 and A3 (56-64\%) than other samples (39-51\%). Well-known electroactive genera of this phylum (such as Geobacter, Pseudomonas, Desulfuromonas, etc.) often play important roles in bioelectroactive biofilms [42,43]. From Figure 7, the Bacteroidetes phylum was the second dominant microorganism in MFCs; it was present the most in A1 (30\%) and the least in A3 (19\%). The presence of Bacteroidetes was previously reported in fermentative bioelectrochemical biofilms due to their ability to biodegrade polymeric proteins and carbohydrates [44,45]. The Firmicutes phylum was often retrieved in bioelectrochemical systems, associated with the electrogenic activity. In this study, it was found in all samples: 10\% for A1 and around 3\% for A2, A3, and A4. Additionally, the presence of Actinobacteria also reflected its assistance in organic degradation since they are known to be members of versatile hydrocarbon degraders [46].

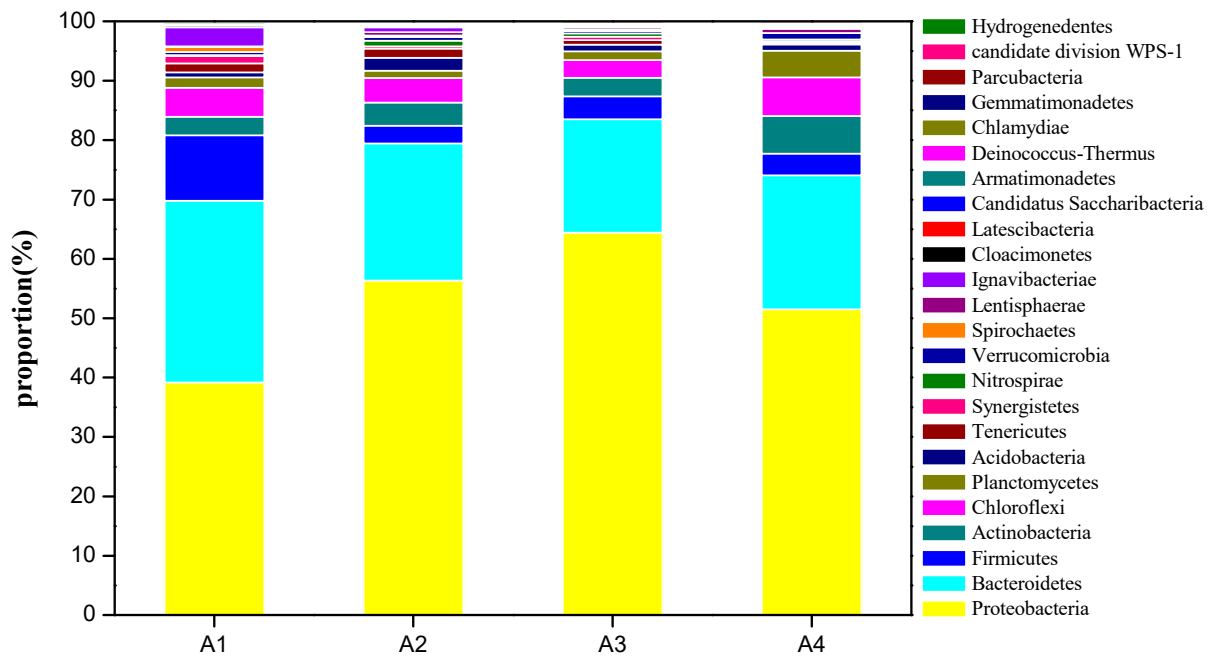

Figure 7. Relative abundance at the phylum level obtained with high-throughput sequencing (A1: 0.1 g zero-valent iron; A2: 0.5 g zero-valent iron; A3: $1 \mathrm{~g}$ zero-valent iron; A4: no zero-valent iron).

Genus-level characterization further illustrated the functional roles of microbes in the MFCs community. PCA analysis of the genus level demonstrated that the dominant microorganism species were various in MFCs. Due to the wide variety of the community, microorganisms, whose relative abundance was more than $3 \%$ and possessed certain functionality, were pre-screened, and then their contributions to MFCs were judged for further analysis. From Figure 8, it was found that Acinetobacter was in the vicinity of first principal component axis and contributed a lot to the axis, indicating that the presence of such a microorganism directly affected the performance of the entire MFCs. In addition, Pelomonas, Arcobacter, and Flavobacterium were also distributed near the main coordinate axis and made such contributions to both axes, so their contents had a certain influence on MFCs to some degree. What is more, it was concluded that the gaps of the angle among the three types of microorganisms, Pseudomonas, Flavobacterium, and Pelomonas, were small, indicating that the three had similar properties 
with a certain affinity when under dosages of the zero-valent iron. Similarly, microorganisms, such as Dechloromonas, Acholeplasma, and Ignavibacterium, had similar gene expression ways in MFCs.

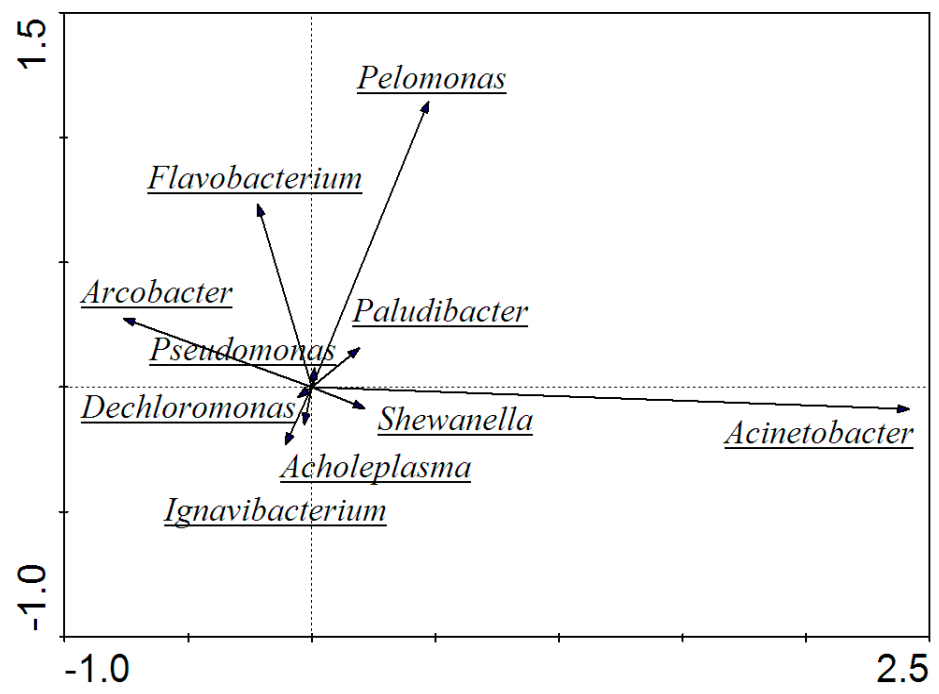

Figure 8. Principal component analysis (PCA) at the genus level.

Furthermore, Figure 9 shows the heat map analysis of the four reactors when different dosages of zero-valent iron were added. It could see that Acinetobacter, Arcobacter, and Pelomonas dominated in thee bacterial community while the distribution of Shewanella and Ignavibacterium in the four reactors was quite different. It is known that the heatmap package of $\mathrm{R}$ language can calculate the Euclidean distance between two samples by using the quantity information, and then cluster samples using the Euclidean distance. After normalizing and rearranging microorganisms, the microorganisms with similar properties will cluster while microorganisms that differ from each other will be far away. Therefore, similar conclusions could be obtained from the heat map.

Redundancy analysis (RDA) is a classification method based on the development of correspondence analysis. Combining the corresponding analysis with the multiple regression analysis, each step of the RDA is calculated with environmental factors, reflecting the relationship between microorganisms and environmental factors. Similar to the data format of PCA, five environmental factors, including voltage, OTUs, Chao, Shannon, and ACE, were selected for RDA analysis of the MFCs system. Arrows mean different environmental factors, and when the angle between environmental factors is less than $90^{\circ}$, this indicates there is a positive correlation between the two factors; otherwise, it is negatively correlated. What is more, the longer the line of the environmental factor, the greater the influence of the impact factor.

In Figure 10, it was found that the angles among the voltage, OTUs, Chao, Shannon, and ACE index were less than $90^{\circ}$, showing a positive correlation between these environmental factors. So, it means that an increase in the abundance of microorganisms as well as community activity could synchronously enhance the electrical performance of the MFC, which is consistent with the results above. Moreover, when the relationship between the microbial community and environmental factors was further analyzed, it was revealed that gaps of the angle between the voltage and microorganisms, such as Acinetobacter, Shewanella, and Pelomonas, were small, showing that these species were closely related to the voltage and Acinetobacter had a greater contribution to the voltage. 


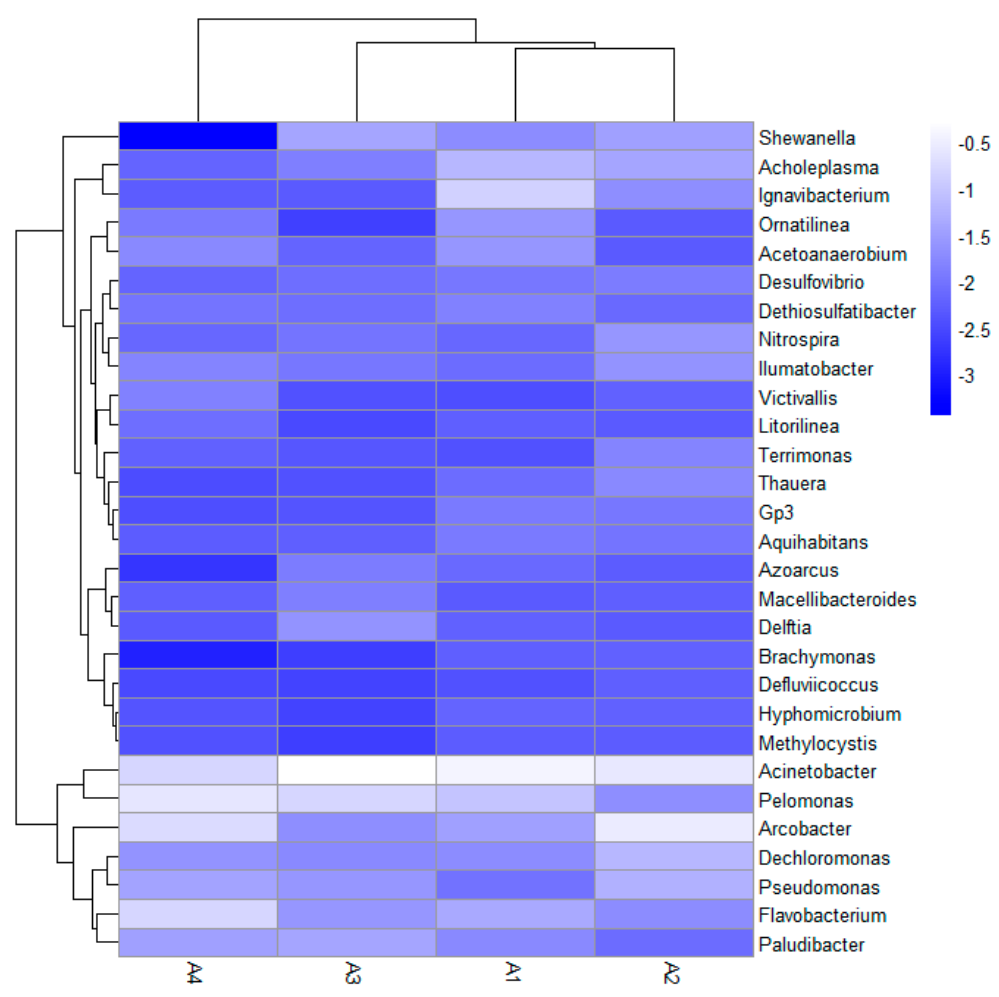

Figure 9. Heat map analysis of the bacterial community structures at the genus level.

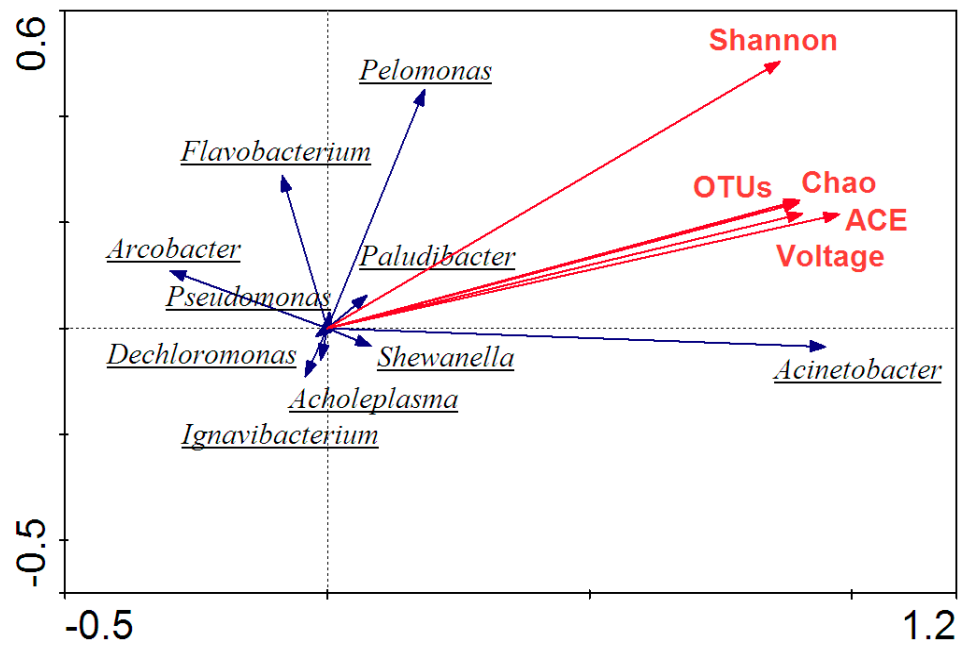

Figure 10. Redundancy analysis at the genus level.

In conclusion, the anode of the MFC is an anaerobic reactor essentially. Acinetobacter was reported to constitute, at least in part, the anodic bacteria in MFCs using anaerobic sludge from wastewater treatment plants as inoculate [47]. In the research of Embree et al. [48] on a single-cell genome and metatranscriptome sequencing of metabolic interactions of an alkane-degrading methanogenic community, he found that unknown members of the orders Ignavibacteriales became more predominant during growth on fatty acids. Therefore, there is a certain relationship between this kind of bacteria and anaerobic fermentation, which may be conducive to methane production. In addition, it was reported that the genus Shewanella was divided into two subgenera on the basis of the phylogenetic structure, growth properties in relation to pressure, and polyunsaturated fatty acid production [49]. Therefore, the addition of zero-valent iron changed the microbial community in the system, and further 
changed the anaerobic digestion process. This was mainly due to its strong reductive property, and zero-valent iron is expected to provide electrons for methanogenesis by producing water-derived $\mathrm{H}_{2}$ during corrosion: $\mathrm{Fe}^{0}+2 \mathrm{H}_{2} \mathrm{O}=\mathrm{Fe}^{2+}+2 \mathrm{OH}^{-}+\mathrm{H}_{2}$. In the above analysis, the abundance of Acinetobacter, Ignavibacteriales, and Shewanella was relatively higher compared to A4, which confirmed the practicability of zero valent iron in an anaerobic digestion system.

In terms of electricity production, Acinetobacter secretes an unidentified endogenous compound similar to pyrroloquinoline quinine and conducts extracellular electrontransfer in MFCs [50]. Meanwhile, it is reported that Arcobacter could contribute to the generation of electricity, with acetate as an electron donor, as they have been isolated from MFC reactors [51]. It was found that Acinetobacter distributed more in A3 and Arcobacter distributed more in A2, which was responsibile for the higher electrochemical performance.

Previous studies have proved the feasibility of employing Shewanella for bioaugmentation on MFC performance [52]. Newton et al. [53] pointed out that Shewanella, which is a widely applicable strain of electroactive microorganisms with a superior capacity for extracellular electron transport, was selected to represent the pure culture inoculum and to develop pure culture MFC-biosensors. Furthermore, Shewanella was discovered by Myers \& Nealson in Lake Oneida, New York, and has been used extensively for Fe reduction in many different systems. They were the first to report the stoichiometric coupling between microbially mediated Fe reduction in clay minerals and the oxidation of organic carbon to $\mathrm{CO}_{2}$, using the $\mathrm{Fe}(\mathrm{III})$-reducing bacterium Shewanella putrefaciens strain MR-1 with formate or lactate as the carbon source [54]. This may be the reason for the low capacity of power generation in A4 because of the lack of zero-valent iron while A2 had the best performance.

In the current research, few reports indicated the effect of zero-valent iron at the acclimation stage in MFC, most of which attempted to improve the electrical performance of MFC by modifying the electrode material or adding agent after the successful start-up of MFC. The invention, by directly adding exogenous zero-valent iron in the domestication stage, using sludge containing iron as an anode substrate to acclimate and enrich electro-producing bacteria in the anode, can not only greatly shorten the start-up time of MFC but also enhance the electricity production of the MFC. Furthermore, this study explained the basic principle of an electro-anaerobic digestion system with zero-valent iron supplementation to the MFC, which provided a practical attempt for further research. In addition, increasing the performance of power generation of the MFC by adding zero-valent iron is practically applicable, because it considers that zero-valent iron or discarded iron filings can be used as raw materials, which are low in price, highly recyclable, environmentally friendly, and in line with the essence of sustainable development.

\section{Conclusions}

Zero-valent iron was added into MFCs' anaerobic reactor at different doses to enhance the electricity generation during the start-up stage in this work. According to the experimental results, the voltage and power density were improved by the zero-valent iron addition. When $0.5 \mathrm{~g}$ of zero-valent iron was added, the maximum values of the voltage and power density were $289.6 \mathrm{mV}$ and $27.3 \mathrm{~mW} / \mathrm{m}^{2}$, accordingly changing the structure of the biofilm and enriching the electro-active microorganisms on the anode electrode, as shown by by SEM observations. Also, carbon felt with zero-valent iron supplemented exhibited relatively superior electrochemical activity and a shifted positive peak oxidation potential as well as decreased resistance, illustrating the much better oxidizing reaction and more active metabolism of exoelectrogens on the surface of the electrode. It was observed that the quantity and diversity of microbial communities was increased, especially Shewanella, which are responsible for electrical generation. In the community, the Proteobacteria phylum was the most abundant in all samples and it was present at higher percentages in both A2 and A3 (56-64\%) than other samples (39-51\%). These results suggested that the performance and anerobic biological community of MFCs can be improved by adding zero-valent iron. 
Author Contributions: Conceptualization, C.L.; Writing—original draft preparation, K.Z.; Formal analysis, H.H.; Methodology, S.Z.; Project administration, J.C. All authors have read and agree to the published version of the manuscript.

Funding: This research was supported by the Major Science and Technology Program for Water Pollution Control and Treatment (No.2012ZX07101-003), National Key R\&D Program of China (2018YFC0406300), the operation for central university of Hohai University (No.2013/B18020148), and A Project Funded by the Priority Academic Program Development of Jiangsu Higher Education Institutions.

Acknowledgments: The authors are grateful for H.H., J.Z., S.Z. and Miaomiao for their laboratory supports and technical assistance.

Conflicts of Interest: The authors declare no conflict of interest.

\section{References}

1. Zeng, L.; Zhang, W.; Xia, P.; Tu, W.; Ye, C.; He, M. Porous $\mathrm{Ni}_{0.1} \mathrm{Mn}_{0.9} \mathrm{O}_{1.45}$ microellipsoids as high-performance anode electrocatalyst for microbial fuel cells. Biosens. Bioelectron. 2017, 102, 351-356. [CrossRef] [PubMed]

2. Xin, X.; Ma, Y.; Liu, Y. Electric energy production from food waste: Microbial fuel cells versus anaerobic digestion. Bioresour. Technol. 2018, 255, 281-287. [CrossRef] [PubMed]

3. Rago, L.; Zecchin, S.; Marzorati, S.; Goglio, A.; Cavalca, L.; Cristiani, P.; Schievano, A. A study of microbial communities on terracotta separator and on biocathode of air breathing microbial fuel cells. Bioelectrochemistry 2018, 120, 18-26. [CrossRef] [PubMed]

4. Deng, L.F.; Li, F.B.; Zhou, S.G.; Huang, D.Y.; Ni, J.R. A study of electron-shuttle mechanism in Klebsiella pneumoniae based-microbial fuel cells. Chin. Sci. Bull. 2010, 55, 99-104. [CrossRef]

5. Santoro, C.; Serov, A.; Gokhale, R.; Rojas-Carbonell, S.; Stariha, L.; Gordon, J.; Artyushkova, K.; Atanassov, P. A family of Fe-N-C oxygen reduction electrocatalysts for microbial fuel cell (MFC) application: Relationships between surface chemistry and performances. Appl. Catal. B Environ. 2017, 205, 24-33. [CrossRef]

6. Zhou, Y.; Tang, L.; Liu, Z.; Hou, J.; Chen, W.; Li, Y.; Sang, L. A novel anode fabricated by three-dimensional printing for use in urine-powered microbial fuel cell. Biochem. Eng. J. 2017, 124, 36-43. [CrossRef]

7. Zhang, E.; Wang, F.; Zhai, W.; Scott, K.; Wang, X.; Diao, G. Efficient removal of nitrobenzene and concomitant electricity production by single-chamber microbial fuel cells with activated carbon air-cathode. Bioresour. Technol. 2017, 229, 111-118. [CrossRef]

8. Commault, A.S.; Laczka, O.; Siboni, N.; Tamburic, B.; Crosswell, J.R.; Seymour, J.R.; Ralph, P.J. Electricity and biomass production in a bacteria-Chlorella, based microbial fuel cell treating wastewater. J. Power Sources 2017, 356, 299-309. [CrossRef]

9. Lovley, D.R. Powering microbes with electricity: Direct electron transfer from electrodes to microbes. Environ. Microbiol. Rep. 2011, 3, 27-35. [CrossRef]

10. He, C.S.; Mu, Z.X.; Yang, H.Y.; Wang, Y.Z.; Mu, Y.; Yu, H.Q. Electron acceptors for energy generation in microbial fuel cells fed with wastewaters: A mini-review. Chemosphere 2015, 140, 12-17. [CrossRef]

11. Chen, G.W.; Choi, S.J.; Cha, J.H.; Lee, T.H.; Kim, C.W. Microbial community dynamics and electron transfer of a biocathode in microbial fuel cells. Korean. J. Chem. Eng. 2010, 27, 1513-1520.

12. Picioreanu, C.; Katuri, K.P.; Loosdrecht, M.C.M.V.; Head, I.M.; Scott, K. Modelling microbial fuel cells with suspended cells and added electron transfer mediator. J. Appl. Electrochem. 2010, 40, 151-162. [CrossRef]

13. Kumar, R.; Singh, L.; Zularisam, A.W. Exoelectrogens: Recent advances in molecular drivers involved in extracellular electron transfer and strategies used to improve it for microbial fuel cell applications. Renew. Sustain. Energy Rev. 2016, 56, 1322-1336. [CrossRef]

14. Pinto, D.; Coradin, T.; Labertyrobert, C. Effect of anode polarization on biofilm formation and electron transfer in Shewanella oneidensis/graphite felt microbial fuel cells. Bioelectrochemistry 2018, 120, 1-9. [CrossRef]

15. Sarma, D.; Barua, P.B.; Dey, N.; Nath, S.; Thakuria, M.; Mallick, S. Investigation and taguchi optimization of microbial fuel cell salt bridge dimensional parameters. J. Inst. Eng. 2018, 1-10. [CrossRef]

16. Zhang, J.; Zhang, Y.; Quan, X.; Chen, S. Effects of ferric iron on the anaerobic treatment and microbial biodiversity in a coupled microbial electrolysis cell (MEC)—Anaerobic reactor. Water Res. 2013, 47, 5719-5728. [CrossRef] [PubMed]

17. Wu, D.; Xing, D.F.; Lu, L.; Wei, M.; Liu, B.; Ren, N. Ferric iron enhances electricity generation by Shewanella oneidensis MR-1 in MFCs. Bioresour. Technol. 2013, 135, 630. [CrossRef] [PubMed] 
18. Varma, S.J.; Muchowska, K.B.; Chatelain, P.; Moran, J. Native iron reduces $\mathrm{CO}_{2}$ to intermediates and end-products of the acetyl-coa pathway. Nat. Ecol. Evol. 2018, 2, 1019-1024. [CrossRef] [PubMed]

19. Liu, Y.; Zhang, Y.; Quan, X.; Li, Y.; Zhao, Z.; Meng, X.; Chen, S. Optimization of anaerobic acidogenesis by adding $\mathrm{Fe}^{0}$, powder to enhance anaerobic wastewater treatment. Chem. Eng. J. 2012, 192, 179-185. [CrossRef]

20. Yakunin, A.F.; Hallenbeck, P.C. Purification and characterization of pyruvate oxidoreductase from the photosynthetic bacterium Rhodobacter capsulatus. Biochim. Biophys. Acta 1998, 1409, 39-49. [CrossRef]

21. Heidrich, E.S.; Dolfing, J.; Wade, M.J.; Sloan, W.J.; Quince, C.; Curtis, T.P. Temperature, inocula and substrate: Contrasting electroactive consortia, diversity and performance in microbial fuel cells. Bioelectrochemistry 2017, 119, 43-50. [CrossRef]

22. Yu, Z.; Yan, M.; Ting, L.; Zhishuai, D.; Yuxue, W. Modification of carbon felt anodes using double-oxidant $\mathrm{HNO}_{3} / \mathrm{H}_{2} \mathrm{O}_{2}$ for application in microbial fuel cells. RSC. Adv. 2018, 8, 2059-2064.

23. Miner, G. Standard Methods for the Examination of Water and Wastewater, 21st ed.; American Public Health Association: Washington, DC, USA, 2005.

24. Jia, H.; Yang, G.; Ngo, H.; Guo, W.; Zhang, H.; Gao, F.; Wang, J. Enhancing simultaneous response and amplification of biosensor in microbial fuel cell-based upflow anaerobic sludge bed reactor supplemented with zero-valent iron. Chem. Eng. J. 2017, 327, 1117-1127. [CrossRef]

25. Ling, R.; Chen, J.P.; Shao, J.; Reinhard, M. Degradation of organic compounds during the corrosion of ZVI by hydrogen peroxide at neutral $\mathrm{pH}$ : Kinetics, mechanisms and effect of corrosion promoting and inhibiting ions. Water Res. 2018, 134, 44-53. [CrossRef] [PubMed]

26. Lin, H.; Zhu, L.; Xu, X.; Zang, L.; Kong, Y. Reductive transformation and dechlorination of chloronitrobenzenes in UASB reactor enhanced with zero-valent iron addition. J. Chem. Technol. Biotechnol. 2011, 86, 290-298. [CrossRef]

27. Meng, X.; Zhang, Y.; Li, Q.; Quan, X. Adding $\mathrm{Fe}^{0}$, powder to enhance the anaerobic conversion of propionate to acetate. Biochem. Eng. J. 2013, 73, 80-85. [CrossRef]

28. Han, T.H.; Cho, M.H.; Lee, J. Indole oxidation enhances electricity production in an E. coli -catalyzed microbial fuel cell. Biotechnol. Bioprocess Eng. 2014, 19, 126-131. [CrossRef]

29. Roy, S.; Saswati, L.S.; Lima, S.; Dhaka, S.; Dinda, R. Synthesis, structural studies and catalytic activity of a series of dioxidomolybdenum(VI)-thiosemicarbazone complexes. Inorg. Chim. Acta 2018, 474, 134-143. [CrossRef]

30. Moyo, B.; Momodu, D.; Fasakin, O.; Bello, A.; Dangbegnon, J.; Manyala, N. Electrochemical analysis of nanoporous carbons derived from activation of polypyrrole for stable supercapacitors. J. Mater. Sci. 2018, 53, 5229-5241. [CrossRef]

31. Lu, L.; Liang, L.; Teh, K.S.; Xie, Y.; Wan, Z.; Tang, Y. The Electrochemical Behavior of Carbon Fiber Microelectrodes Modified with Carbon Nanotubes Using a Two-Step Electroless Plating/Chemical Vapor Deposition Process. Sensors 2017, 17, 725. [CrossRef]

32. Choi, T.S.; Song, Y.C.; Timothy, H. A facile method for preparation of efficient oxygen reduction catalyst for a microbial fuel cell cathode. KSCE J. Civ. Eng. 2017, 1-9. [CrossRef]

33. Sumisha, A.; Haribabu, K. Modification of graphite felt using nano polypyrrole and polythiophene for microbial fuel cell applications-a comparative study. Int. J. Hydrogen Energy 2018, 43, 3308-3316. [CrossRef]

34. Rosenbaum, M.; He, Z.; Angenent, L.T. Light energy to bioelectricity: Photosynthetic microbial fuel cells. Curr. Opin. Biotechnol. 2010, 21, 259-264. [CrossRef] [PubMed]

35. Mateo, S.; Gonzalez, D.C.A.; Cañizares, P.; Lobato, J.; Rodrigo, M.A.; Fernandez, F.J. Bioelectricity generation in a self-sustainable Microbial Solar Cell. Bioresour. Technol. 2014, 159, 451-454. [CrossRef] [PubMed]

36. Karthikeyan, R.; Uskaikar, H.P.; Berchmans, S. Electrochemically Prepared Manganese Oxide as a Cathode Material for a Microbial Fuel Cell. Anal. Lett. 2012, 45, 1645-1657. [CrossRef]

37. In, S.I.; Kim, H.W.; Lee, K.S.; Razzaq, A.; Lee, S.H.; Grimes, C.A. Photocoupled Bioanode: A New Approach for Improved Microbial Fuel Cell Performance. Energy Technol. 2017, 6, $257-262$.

38. Kim, K.Y.; Yang, E.; Lee, M.Y.; Chae, K.J.; Kim, C.M.; Kim, I.S. Polydopamine coating effects on ultrafiltration membrane to enhance power density and mitigate biofouling of ultrafiltration microbial fuel cells (UF-MFCs). Water Res. 2014, 54, 62-68. [CrossRef]

39. Kouzuma, A.; Ishii, S.; Watanabe, K. Metagenomic insights into the ecology and physiology of microbes in bioelectrochemical systems. Bioresour. Technol. 2018, 255, 302-307. [CrossRef] 
40. Chen, L.; Zhang, P.; Shang, W.; Zhang, H.; Li, Y.; Zhang, W.; Zhang, Z.; Liu, F. Enrichment culture of electroactive microorganisms with high magnetic susceptibility enhances the performance of microbial fuel cells. Bioelectrochemistry 2018, 121, 65-73. [CrossRef]

41. Antwi, P.; Li, J.; Boadi, P.O.; Shi, E.; Meng, J.; Chi, X.; Deng, K.; Ayivi, F. Dosing effect of zero valent iron (ZVI) on biomethanation and microbial community distribution as revealed by $16 \mathrm{~S}$ rRNA high-throughput sequencing. Int. Biodeterior. Biodegrad. 2017, 123, 191-199. [CrossRef]

42. Patil, S.A.; Surakasi, V.P.; Koul, S.; Ijmulwar, S.; Vivek, A.; Shouche, Y.S.; Kapadnis, B.P. Electricity generation using chocolate industry wastewater and its treatment in activated sludge based microbial fuel cell and analysis of developed microbial community in the anode chamber. Bioresour. Technol. 2009, 100, 5132-5139. [CrossRef] [PubMed]

43. Borole, A.P.; Mielenz, J.R.; Vishnivetskaya, T.A.; Hamilton, C.Y. Controlling accumulation of fermentation inhibitors in biorefinery recycle water using microbial fuel cells. Biotechnol. Biofuels 2009, 2, 7. [CrossRef] [PubMed]

44. Rago, L.; Cristiani, P.; Villa, F.; Zecchin, S.; Colombo, A.; Cavalca, L.; Schievano, A. Influences of dissolved oxygen concentration on biocathodic microbial communities in microbial fuel cells. Bioelectrochemistry 2017, 116, 39-51. [CrossRef] [PubMed]

45. Montpart, N.; Rago, L.; Baeza, J.A.; Guisasola, A. Hydrogen production in single chamber microbial electrolysis cells with different complex substrates. Water Res. 2015, 68, 601-615. [CrossRef]

46. Lu, L.; Huggins, T.; Jin, S.; Zuo, Y.; Ren, Z.J. Microbial metabolism and community structure in response to bioelectrochemically enhanced remediation of petroleum hydrocarbon-contaminated soil. Environ. Sci. Technol. 2014, 48, 4021-4029. [CrossRef]

47. Yusoff, M.Z.; Hu, A.; Feng, C.; Maeda, T.; Shirai, Y.; Hassan, M.A. Influence of pretreated activated sludge for electricity generation in microbial fuel cell application. Bioresour. Technol. 2013, 145, 90-96. [CrossRef]

48. Embree, M.; Nagarajan, H.; Movahedi, N.; Chitsaz, H.; Zengler, K. Single-cell genome and metatranscriptome sequencing reveal metabolic interactions of an alkane-degrading methanogenic community. ISME J. 2013, 8 , 757. [CrossRef]

49. Toffin, L.; Bidault, A.; Pignet, P.; Tindall, B.J.; Prieur, D. Shewanella profunda sp. nov. isolated from deep marine sediment of the Nankai Trough. Int. J. Syst. Evolut. Microbiol. 2004, 54 Pt 6, 1943. [CrossRef]

50. Freguia, S.; Tsujimura, S.; Kano, K. Electron transfer pathways in microbial oxygen biocathodes. Electrochim. Acta 2010, 55, 813-818. [CrossRef]

51. Zhao, H.; Kong, C.H. Elimination of pyraclostrobin by simultaneous microbial degradation coupled with the Fenton process in microbial fuel cells and the microbial community. Bioresour. Technol. 2018, 258, 227. [CrossRef]

52. Kumar, G.; Bakonyi, P.; Kobayashi, T.; Xu, K.Q.; Sivagurunathan, P.; Kim, S.H.; Buitron, G. Enhancement of biofuel production via microbial augmentation: The case of dark fermentative hydrogen. Renew. Sustain. Energy Rev. 2016, 57, 879-891. [CrossRef]

53. Newton, G.J.; Mori, S.; Nakamura, R.; Hashimoto, K.; Watanabe, K. Analyses of current-generating mechanisms of Shewanella loihica PV-4 and Shewanella oneidensis MR-1 in microbial fuel cells. Appl. Environ. Microb. 2009, 75, 7674. [CrossRef] [PubMed]

54. Pentráková, L.; Su, K.; Pentrák, M.; Stucki, J.W. A review of microbial redox interactions with structural Fe in clay minerals. Clay Miner. 2013, 48, 543-560. [CrossRef]

(C) 2020 by the authors. Licensee MDPI, Basel, Switzerland. This article is an open access article distributed under the terms and conditions of the Creative Commons Attribution (CC BY) license (http://creativecommons.org/licenses/by/4.0/). 